\title{
Nervous System Findings Group Identifier
}

National Cancer Institute

\section{Source}

National Cancer Institute. Nervous System Findings Group Identifier. NCI Thesaurus.

Code C162011.

A character or string that represents a nervous system findings group. 